UDK 37:929 Станковић 3. “1968/2020“

IN MEMORIAM

DOI: https://doi.org/10.46630/gped.1.2020.08

\title{
In memoriam \\ Проф. др ЗОРАН СТАНКОВИЋ \\ (1968-2020)
}

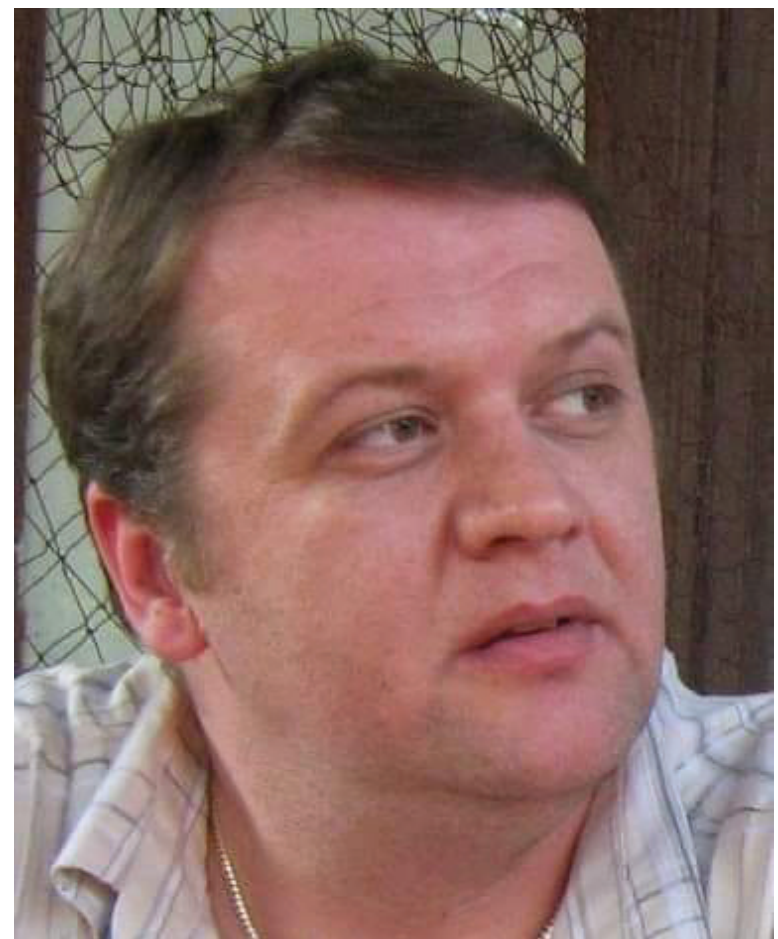

Уважени чланови породице, драги Данило и драга Александра,

Поштоване колеге и пријатељи,

Са великим болом и неверицом сазнали смо тужну вест да се 30. маја 2020. године, после краће болести, изненада упокојио наш уважени и драги колега, др Зоран Станковић, ванредни професор на Департману за педагогију 
Филозофског факултета Универзитета у Нишу. Само десетак дана раније интензивно смо сарађивали на редовним пословима, на бројним заједничким научним и стручним пројектима, као и на питањима реализације и унапређења наставе у најновијим ванредним околностима, а данас смо принуђени да се неповратно опраштамо од њега. Све то изазвало је огромну тугу и ожалошћеност свих чланова Департмана за педагогију, као и наше дубоко саучешће у болу са његовом сестром, мајком и оцем, а поготово са члановима најуже породице, сином Данилом и супругом Александром, о којима је наш драги колега Зоран причао са великом љубављу и којима је био истински посвећен и као брижни отац и као одани супруг.

Зоран Станковић је рођен у Алексинцу 14. 10. 1968. године. Образовање је започео у родном граду, где је завршио нижу музичку, основну и средњу школу, а затим је основне, магистарске студије, као и докторат наука завршио на Учитељском/Педагошком факултету Унивезитета у Нишу. Похађао је и завршио Студије разредне наставе на Педагошкој академији „Душан Тривунац“ у Алексинцу (1988-1991), а потом је наставио усавршавање на Студијама разредне наставе на Учитељском факултету у Врању (1994-1997). Постдипломске студије и одбрану магистарског рада „Примена наставе на више нивоа сложености мултимендијалним приступом у настави природе и друштва“" окончао је 2003. године на Учитељском факултету Универзитета у Нишу са седиштем у Врању, под менторством проф. др Боре Станимировића. Докторирао је из области дидактичко-методичких наука, на теми „Индивидуализација методичких модела наставе применом електронског уџбеника (образовног софтвера)“, на Педагошком факултету Универзитета у Нишу, са седиштем у Врању, у пролеће 2014. године, под менторством проф. др Марјана Блажича.

Зоран Станковић је остварио садржајну професионалну каријеру. Радио је најпре као професор (разредне и предметне наставе) у Специјалној основној школи „Владимир Ђорђевић“ у Алексинцу (1997-2000), а потом и као наставник практичне наставе у Вишој школи за васпитаче у Алексинцу (2000-2004). На Филозофски факултет у Нишу дошао је почетком 2004. године и радио у звању асистента на тада новооснованом Департману за педагогију (2004-2014). Одмах по одбрањеном докторату наука 2014. године, изабран је и предавао је у звању доцента (2014-2019), да би средином 2019. године био изабран и од тада предавао у звању ванредног професора. У том наставнонаучном звању га је затекла и ненадана болест и смрт.

За све то време обављао је различите одговорне функције на Филозофском факултету у Нишу. Био је секретар Департмана за педагогију (2005-2007), главни и одговорни уредник Годишњака за педагогију (од 2017. године), као и управник Департмана за педагогију (од школске 2016/17. године). У широј друштвеној заједници исказао се активним деловањем у оквиру Друштва педагога Србије, чији је члан постао 2014. године.

Објавио је две монографије и више научних и стручних студија у домаћим и страним часописима, као и зборницима радова и тематским публикацијама из области педагогије. Учествовао је на активан начин на бројним научним 
конференцијама у земљи и иностранству. Овом приликом посебно по научном доприносу издвајамо две његове објављене монографске публикације: Примена наставе на више нивоа сложености мултимедијалним приступом (Филозофски факултет Ниш, 2004) и Дидактичке иноващије у теорији и наставној пракси (у коауторству са проф. др Драганом Станојевић) (Филозофски факултет Ниш, 2019). Указујемо и на три веома успешна емпиријски верификована образовна софтвера за децу предшколског и млађег школског узраста.

Научни приступ уваженог и драгог колеге, проф. др Зорана Станковића, карактерисала је изразита мултидисциплинарна оријентација, усмерена на истраживања у дидактичко-методичкој области, као и на поље савремених образовних и информационо-комуникационих технологија. При томе је увек показивао сасвим поуздану методолошку утемељеност у емпиријским истраживањима. Изградио је добра теоријска полазишта, као и потпуну и конзистентну информисаност о бројним домаћим и иностраним истраживачима и њиховим достигнућима. Посебну вредност представља чињеница да су наведени истраживачки резултати и сазнања у целости примењиви у непосредној наставној пракси и значајно доприносе оспособљавању предавача на свим образовним нивоима. Са изузетном лакоћом уочавао је актуелна проблемска питања у области унапређења наставе, а затим је на њих давао креативне одговоре, као и методичка практична решења, који су подстицали бројне друге истраживаче на даља разматрања истих и сродних проблема.

На пољу универзитетске наставе, још од избора у звање асистента на Филозофском факултету у Нишу, а потом и у наставничким звањима доцента и ванредног професора, показивао је изразиту посвећеност у раду са студентима на основним, мастер и докторским академским студијама, на бројним предметима: Методика васпитно-образовног рада, Дидактичке иновације, Мултимедијални системи у образовању, Образовне технологије, Педагошка информатика, Стратегије ефикасног образовања, Методика наставе техничко-технолошких предмета, Дидактика медија, Методичко моделовање наставе. Био је предан и несебичан ментор бројним студентима који су радили завршне и мастер радове, а исту врсту посвећености и преданости показивао је и у сарадњи са млађим сарадницима, са свим колегама са Департмана за педагогију, као и сарадницима и наставницима читавог Филозофског факултета и других универзитета и научних института у земљи и иностранству.

Функцију управника Департмана за педагогију Филозофског факултета Универзитета у Нишу обављао је предано и коректно, настојећи да у сталном договору са колегама, као први и најодговорнији међу једнакима, пронађе најбоља решења за стално унапређење и развој студијских програма, као и непосредно извођење наставе на тим програмима. Сличну врсту посвећености, преданости, добронамерности и одговорности показивао је и као главни и одговорни уредник научног часописа Годишњак за педагогију.

На крају овог некролошког казивања, дубоко преплављена тугом и неверицом, дозволићете ми да будем субјективна и укажем на бројне примере личне научне и наставне сарадње са колегом Зораном, у којој сам сваки пут 
изнова могла посведочити његовим високим научним и људским квалитетима. Спознала сам то и као члан његове комисије за одбрану докторске дисертације, као и комисије за његов избор у наставно-научна звања доцента и ванредног професора. Сарађивали смо и као рецензенти научних публикација, те као чланови бројних комисија за одбрану дипломских, завршних и мастер радова, а са поносом наглашавам да смо урадили и више заједничких научних истраживања. Један део тога смо и објавили у водећим домаћим и међународним часописима, а неки радови ће ускоро тек бити објављени, али њихово излажење колега Зоран, нажалост, неће дочекати. Најсвежији и најпотпунији утисак на мене је оставила непосредна сарадња на рецензији рукописа уџбеника Статистички тестови у педагошким исражовањима, који сам урадила заједно са колегиницом Јеленом Османовић, а за који нам је колега Зоран дао читав низ несебичних, корисних и прецизних сугестија без којих ова публикација не би добила овако јасну уџбеничку концепцију.

Прерано упокојење нашег уваженог и драгог колеге, проф. др Зорана Станковића, као брижног оца и оданог супруга, посвећеног брата и сина, увек ће представљати највећи губитак и патњу за његову породицу и најближе. За Филозофски факултет у Нишу, а посебно за Департмана за педагогију, представљаће ненадокнадив одлазак наставника и колеге у оним професионалним годинама када је био спреман највише да допринесе и својој институцији и својој научној заједници.

Нека му је вечна слава и хвала!

\section{Проф. др Јелена Максимовић Департман за педагогију Филозофски факултет у Нишу}

Цитирање чланака: Максимовић, J. (2020). In memoriam - Prof. dr Zoran Stanković (1968 - 2020). Godišnjak za pedagogiju, 5(1), 105-108. 